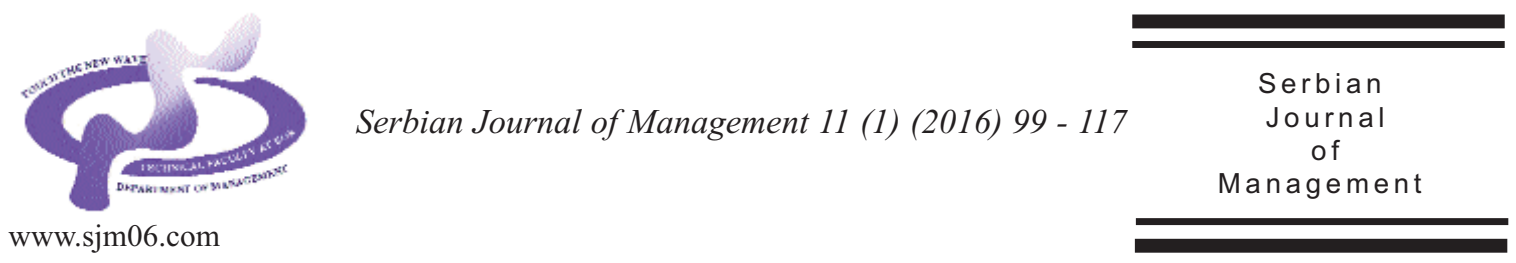

\title{
EXPLORING THE RELATIONSHIP BETWEEN LEADERSHIP COMMUNICATION STYLE, PERSONALITY TRAIT AND ORGANIZATIONAL PRODUCTIVITY
}

\author{
Oludele Mayowa Solaja*a ${ }^{*}$ Faremi Elijah Idowu ${ }^{b}$ and Adesina Ekundayo James ${ }^{b}$ \\ a Olabisi Onabanjo University, Department of Sociology, Ogun State, Nigeria \\ ${ }^{b}$ Olabisi Onabanjo University, Department of Business Administration, Ogun State, Nigeria
}

(Received 20 May 2015; accepted 30 december 2015)

\begin{abstract}
In organizational research and practice, prolific communication is significantly linked with quality leadership traits. Leadership quality helps in mitigating the failure of an organization to survive the increasing business challenges that may result in waste of resources, talents and potentials needed for achieving optimal organizational productivity. However, an examination of academic literatures reveal that corporate leaders are often faced with the challenge of how to move smoothly between different communication styles to communicate clearly articulating ideas and knowledge to employee's whenever the occasion demands which hinders organizational productivity. Against this background, this study explores the relationship between leadership communication style, personality trait and organizational productivity. The study utilized cross-sectional survey method. Participants were 112 academic staff of University of Lagos, Nigeria who was selected through multi-stage sampling techniques. Data were collected through structured questionnaire and personal observation. Results show that there exists a connection between leadership communication style and personality trait. Also, the finding revealed that leadership communication style determines organization productivity. More so, the finding established that personality traits and communication styles have combine effect on organizational productivity. Conclusively, the findings were discussed with reference to relevant empirical literatures with recommendations for management of organizations both for practice and future research highlighted.
\end{abstract}

Keywords: leadership, communication, style, personality trait, productivity, organization

\section{INTRODUCTION}

Leadership position stands as one of the subtle positions in today's corporate organizations. It is a position that must be assigned or emerged based on merits. Leadership based on political calculations or nepotisms will not drive organizational

\footnotetext{
* Corresponding author: postgraduatescholar@gmail.com DOI:10.5937/sjm11-8480
} 
productivity positively (DfES, 2002). Hence, to merit a leadership position in an organizational setting; certain extra-ordinary qualities must be demonstrated by the anticipated candidate or contestant. These qualities must be in line with the organizational values and requirements for accomplishing the set goals and objectives. The justification for fulfilling these requirements is to ensure that the candidate have the capacity to think outside the box and to withstand the pressure emanating from the process of managing mix of individuals with variety of personalities, values and attitudes toward realizing organizational goals (Nwagwu, 2014). This suffices to point out that any candidate that fails to meet the criteria for leadership position (such as goal commitment, honesty, temperament, diligence, courage, justice etc.) will definitely fail in shouldering the leadership functions (i.e. planning, budgeting, controlling, organizing, and coordinating the group members' activities) and the organization would not be able to stand the test of time (Nwagwu, 2014; Ajila, 2014).

Among the qualities that a candidate seeking leadership position must demonstrate is the ability to communicate ideas, build support, negotiate and speak effectively within and outside the organization using the appropriate communication styles (Ticehurst \& Veal, 2000). The ability to communicate information effectively with others (coworkers) help a leader to identify work problem, resolve it and maintain a smart organization-an organization that is safe, principle driven and value focused (Grint, 2004). As a matter of fact, no matter how brilliant or experience a leader may be, if $\mathrm{s} /$ he lacks effective communication skills, then $\mathrm{s} /$ he will definitely fail in the management aspect of coordinating, organising, planning and controlling the work/workforce toward achieving the set targets. This is so because; poor communication skill will ultimately hinders the process of sending, receiving, processing and retrieving information between superior and subordinates in their attempt to drive organizational productivity effectively.

Perhaps, this is the foremost reason why The Public Forum Institute in 2001 emphasized that today's leaders must acquire effective communication skills for public speaking, listening and critical thinking in order to promotes organizational performance and cordial relationship between the organization and the external public (www.publicforuminstitute.org).The extent to which a leader exhibits outstanding communication skills determine the kind of corporation s/he will get from subordinates and by extension translates to increase productivity and performance. In the same view, Nwagwu (2014) conceived that it is significantly remarkable for information and knowledge to flow freely and effectively between the leader and the subordinate (s) and horizontally between subordinates working together with the aim of achieving outstanding success for the organization in today's knowledge driven economy.

Accordingly, Weihrich and Koontz (1993), in its broadest sense stated that:

The purpose of communication in an organization is to effect change and to influence action toward the welfare of the organization. Communication is essential for the internal functioning of enterprises because it integrates the managerial functions. It is especially needed to establish and disseminate the goals of an enterprise; develop plans for their achievement; 
organize human and other resources in the most effective and efficient way; select, develop, and appraise members of the organization; lead, direct, motivate, and create a climate in which people want to contribute; and control performance.

Certainly, the style of communicating ideas, information and knowledge in a joint or collective activity is imperative; without effective communication style among the group of individuals, the intensity to attain collective goals will be difficult (if not impossible). Of course, in fostering the place of strategic management in contemporary organization; leading, coordinating and communication helps to relates organizational purpose with people's worldview, specifically their political and social behaviours which are very germane for the functioning of the organization. However, it is very important to note that for communication to produce the desired effect; information must be processed, transmitted and decoded in a simple and unambiguous language to facilitate better understanding and to motivate the recipient ' $\mathrm{s}$ ' to act on the information as intended (Den Hartog \& Koopman, 2011). In other words, if information is vague then communication has not taken place.

Meaningful information often emanated from open minded individuals who use effective communication skills as enabler to achieve the desired goals (Den Hartog \& Koopman, 2011). However, to ascertain leaders with effective communication styles who can excellently achieve desirable organizational performance and productivity; personality traits could be a gauge without conducting laboratory experiment. Just as Ajila, Akanni and Ekundayo (2012) noted that personality traits is a credible factor for predicting behaviour, potentials, skills and abilities of people in work organization without resorting to any psychological test. It is on this reality, this study set out to explore the relationship between leadership communication style, personality trait and organizational productivity.

\subsection{Motivation for the Study}

This study is imperative because it aim to provide logical ways on how leaders can build different communication styles and personality traits that can influence employee's performance toward achieving increase productivity in contemporary business organizations. This study is relevant in the sense that leaders must produce desirable effect in their working environment by processing and disseminating crucial information that will facilitate employee's complete understanding of the next line of action and motivates them to act on the information effectively. This study will contribute new areas of research focus and knowledge in leadership education and organizational productivity.

\section{CONCEPTUALIZATION OF VARIABLES}

\subsection{Communication Style}

Communication style means the individual way of thinking, temperament and perception of social reality during interaction or dissemination of information (Norton, 1983; Kirtley \& Weaver, 1999). It can also be viewed as the manner which communicator adopts in making audience or listeners of certain information to conceive the information in order to influence their action 
and understanding (Ticehurst \& Veal, 2000). Implicitly, communication style is natural and culturally nurtured. Therefore, it is individualistic and it is determined by the way people conduct themselves, perceives and observed others as well as their perspectives on social reality. Consequently, communication style plays pivotal role in workplace relationships at vertical and horizontal level of organizational communication.

Martinez (2012) emphasized that good communication style is essentially needed in managing workforce or team effectively in order to have good production outcomes. The U.S Department of Labor observed similar view, by submitting that communication competency is a vital skill necessary for managers and leaders in $21^{\text {st }}$ century for organizational success in spite of the stringent competitive business environment (Secretary's Commission on Achieving Necessary Skills, 1992). Because, recent economic is shifting from manufacturing to service careers, the ability to communicate with others has become crucial. Therefore, it is necessary for us to examine common forms of communication style that can be found in most work organization.

\subsection{Forms of Communication Style}

Several forms of communication style has been identified by psychologists and management experts, however, Norton (1983) classifies communication styles into ten types which are:

(i) Dominant style where an individual takes control of social situations,

(ii) Dramatic style in which a person is verbally alive with picturesque speech,

(iii) Contentious style where a person is argumentative or quick to challenge others,

(iv) Animated style where an individual is nonverbally active,

(v) Impression-leaving style where someone displays communication stimuli that are easily remembered,

(vi) Relaxed style in which a person is at ease and not conscious of any nervous mannerism,

(vii) Attentive style through which an individual is empathetic and listens carefully,

(viii) Open style where someone is unreserved, somewhat frank and possibly outspoken,

(ix) Friendly style where a person confirms, strokes and positively recognizes others, and

(x) Precise style in which a communicator asks for precise and accurate content of communication and conversations.

However, in deciding which of the above communication styles a leader must adopts for effective operation and performance within the work system; a systematic examination of factors such as organizational structure, workforce composition, working environment (internal and external), organizational culture, corporate policy, vision and mission statements, external competitors etc. must be carried out.

\subsection{Personality Traits}

Personality traits mean a pattern of behaviour, thought and emotion that are fairly consistent throughout life (Mathews et al., 2003). It can also be referred as individual's characteristic patterns of thought, emotion and behaviour that give both consistency and individuality to a person's (Funder, 1997; Feist \& Feist, 2009). However, personality traits may be 
transmitted to the next generation because it consists of both heredity and environmental features of a person (Ajila, 2014). According to Ajila (2014) this can be seen when we compare the physical likeness of parents and offspring in which the potential abilities of offspring also show similarities with those of their parents. For instance, if a member of the family is a good worker on a given kind of job or responsibility, there is some probability that his siblings will be equally satisfactory both in temperament and in potential ability. Similarly, musicians, football players, expert machinists, and the like appear too commonly in some families due to hereditary factors.

On the other hand, environmental factors which include biological, physical, psychological and geographical conditions where individuals exist generally have more dominant influence on personality traits and interests. Within this potential level of development an individual can optimally achieve and at the same time fail to achieve certain goals and objectives. Thus, environmental factors have an important influence on the level of development that actually occurs.

\subsection{Determinant of Personality traits}

Psychologists have reported that there are key factors that determine individual personality traits (Digman, 2000; John et al., 2008). These factors are referred to as 'The Big Five' personality traits. These five traits, according to many, make up the OCEAN of human personality, as the acronym goes, and are often considered to be the basic traits under which all other aspects of personality fall. These factors are: i. Openness: This refers to the dimension ranging from outgoing, liberal, interested in new things, and imaginative to reserved, conservative, traditional, and conforming.

ii. Conscientiousness: This refers to the continuum ranging from organized, careful, and determined to careless, and weak willed. Those on the high end of this factor may be seen as stoic, cold, and methodical. Those on the low end may be seen as gullible, followers, or may see the needs of others as always superceding their own.

iii. Extraversion: This refers to a person who prefers group activities, group sports, large gatherings, lots of friends and acquaintances, loud music, and social endeavors. An introvert prefers more solitude, quiet music, small groups or individual sports and would rather stay at home or engage in a small group activity than attend a party or large social gathering.

iv. Agreeableness: represents the extremes of stubborn versus easy going or suspicious versus trusting. Those high in agreeableness are helpful, sympathetic to others, and understanding. Those low on this trait are seen as argumentative, skeptical, and strong-willed.

v. Neuroticism or emotion stability: this refers to the dimension of emotional stability. Someone high on neuroticism would exhibit instability in his or her emotions, interactions, and relationships. They may have frequent and wide mood swings, be difficult to understand, and become more upset over daily stressors and interactions. The person low on neuroticism may be seen as reserved, calm, and perhaps even unemotional. 


\subsection{Linking Leadership Communication Style to Personality Traits}

It is important to note that behaviour serves as the edifice upon which effort at linking leadership communication style and personality trait is carried out in this study. Since personality trait is the habitual pattern of behaviour, thought and emotion that are fairly consisted throughout life (Mathews et al., 2003). As such, some scholars in industrial psychology have linked behaviour in organization to six personality traits (French et al., 1985; Robbins et al., 2009; Ajila 2014) which include:

i. Locus of control: This deals with twofold of behaviour that people exhibit in reaction to social events or phenomenon. Some people believe they control their own fate while others see themselves as pawn of fate, believing that what happens to them in their lives is due to luck or chance. The locus of control in the first case is internal; and in the second case is external. Therefore, leader who believes that his life is controlled by external forces may likely adopt contentious or relaxed styles of communication. This may also lead to low job satisfaction, alienation from work setting, poor knowledge management as well as blame poor performance on his subordinates. Whereas, leader who believes that he control his destiny by himself may embrace dramatic, animated, impression-leaving, open, friendly and precise styles of communication. This in turn increases his job satisfaction, commitment, sense of acceptance of responsibility and evaluation of performance in terms of his actions.

ii. Authoritarianism: This centered on the belief that there should be differences in status and power among people in organization. The extremely high authoritarian leaders are intellectually rigid, judgmental of other, deferential to those in positions above them, exploitative to those in position below them, distrustful, and resistant to change. Therefore, a high authoritarian leader may adopt contentious and dominant communication styles which may negatively affect the performance of a job that demands sensitivity to feelings of others and the ability to adapt to complex and dynamic situations.

iii. Machiavellianism: This is a way similar to authoritarianism however; a Machiavellianism leader is pragmatic, maintains emotional distance and believes that ends justify means. His highly productive in jobs or responsibilities that require bargaining skills or that have substantial reward for winning. While, in jobs where ends do not justify the means or lack absolute measure of performance, it is difficult to predict his performance. Hence, a high Machiavellian leader may utilize relaxed, contentious and dominant communication styles in the workplace.

iv. Self-esteem: this is the degree to which people like or dislike themselves that is directly related to expectations for success. High self-esteem leaders possess more ability then they need to perform the leadership responsibilities in order to succeed at work. Thus, they may adopt dramatic, relaxed, impression-leaving, friendly, open and precise communication styles. While, leaders while low self-esteem are more subject to external influence and dependent on receiving positive evaluation from others. As such, they tend to be concerned with pleasing others and therefore, less likely to take unpopular stands on matters. Thus, a low self-esteem leader may embrace animated, attentive and precise 
styles of communication in work organization.

v. Self-Monitoring: This refers to an individual's ability to adjust his or her behaviour to external, situational factor. They are highly sensitive to external cues and can behave differently in different situations. Leaders with high self-monitor are capable of presenting striking contradictions between their public personal and their private selves. The high selfmonitor is capable of putting on different "faces" for different audiences. Hence, they are likely to adopt dominant, animated, attentive and friendly communication styles. While, leaders with low self-monitors can't deviate from their behaviour. They tend to display their true dispositions and attitudes in every situation, and there's high behavioural consistency between who they are and what they do. They may utilize dramatic, open, precise and impression-leaving styles of communication in the work place.

vi. Risk Taking: People differ in their willingness to take chances. This propensity to assume or avoid risk has been shown to have an impact on how long it takes leaders to make a decision and how much information they require before making their choice. Leaders with a high risk propensity make more rapid decisions and use less information in making their choices than lower risk propensity leaders. They are most likely to use dominant, contentious, relaxed and open styles of communication. On the other hand, low risk taking leaders may employ dramatic, animated, attentive, impression-leaving and precise communication styles.

Diagrammatical illustration linking leadership communication style to personality trait is provided in Figure 1.

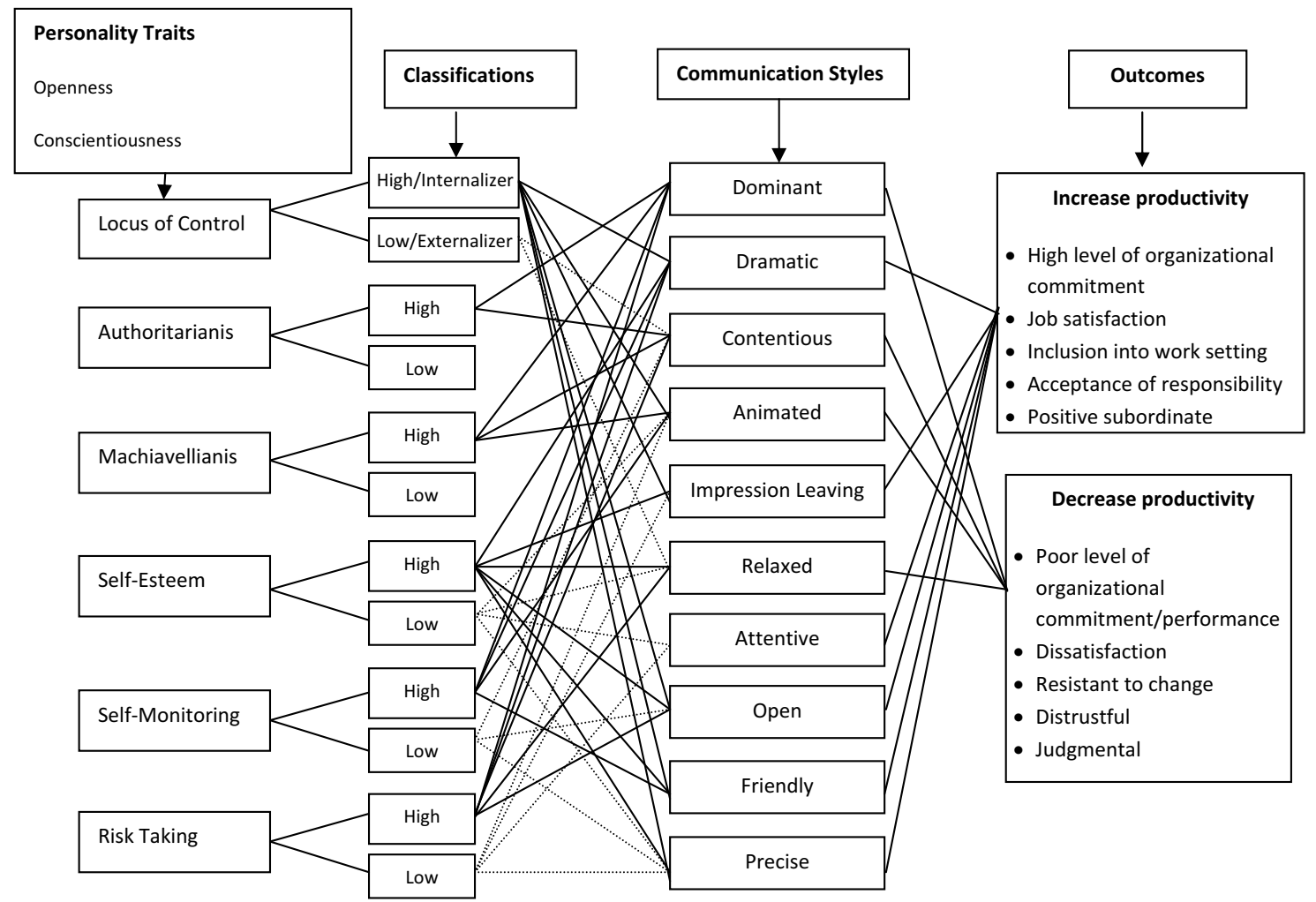

Figure 1. Showing the Nexus between Personality Traits and Communication Styles 


\subsection{Organizational Productivity}

Economists conceived the word productivity to mean the ratio of output volume to input volume in production (Phusavat, 2007; Dixon et al., 1990). That is, an average measure of production given efficient use of innovation and resources (human, financial and material) to increase the values added content of products and services (Phusavat, 2007). However, organizational productivity can be defined as the amount of goods and services that a workforce produces in a given amount of time, resources, machines and environment in order to bring about improvement in standard of living, economic growth production margin, profit maximization and organizational competitiveness. Hence, an organization is productive if it achieves its goals by transforming inputs into outputs at the lowest cost without any wastage. As such, productivity implies a concern for both employee effectiveness and managerial efficiency. Hence, it is the driving force behind a company's growth and profitability.

\subsection{Factors Affecting Organizational Productivity}

In management studies, there are four basic factors that influence organizational productivity. These factors are:

i. Environmental Factor: This deals with the geographic, political and economic environment in which an organization operates its level of productivity. It is very difficult for any organization to control the environmental factors; therefore, the organization must always be flexible in adapting to them.

ii. Organizational factor: An organization structure, technology and climate affect its efficiency, productivity and profitability. These profound influences must be considered and handled by the leader or manager.

iii. Managerial factor: Every organization has its pattern of management consciously designed, adopted or naturally evolved. It could be task oriented, democratic, laissez faire and "laid back" or authoritarian. Managerial style has a direct effect on its employees and how leader will communicate information or knowledge whether through an open network or not, how change can be instituted, all significantly influence the leadership function.

iv. Employee-related factor: Attitude of employees may have the strongest effect on the organizational productivity. Because employees are the means by which the organizational goals are achieved, they drive a company success or failure. Therefore, employee's attitudes, abilities and motivation are highly important to organizational productivity.

\section{THEORETICAL FRAMEWORK}

\subsection{Affective Events Theory}

Affective events theory (AET) is a model developed by Weiss and Cropanzano (1996) to discover how emotions and moods influence job performance and job satisfaction. AET proposes that organizational events are proximal causes of effective reactions. By implication, "things happen to people in work setting and people often react emotionally to these events (Weiss \& Cropanzano, 1996). It suggested and hypothesized relationship between moment-to-moment emotions and outcomes 
such as effectiveness of leadership communication style, personality trait and employee's reaction to organizational performance and productivity (Alter, 2006; Steijn 2001). Furthermore, AET increases the understanding of employee's reactions to leadership communication style and personality trait at workplace. AET believes that work modelled includes hassles, autonomy, job demands, and emotional labour as well as uplifting actions of their reactions. This emotional response intensity therefore affects organizational performance and productivity. In addition, affective events theory also proposes that stable work features such as job scope predisposes the occurrence of certain types of affect producing events. For instance, an enriched leadership communication style and personality trait leads to events involving feedback, task accomplishment, and optimal challenge that may result in workers happiness and enthusiasm.

Figure 2 howing the conceptual framework of relationship between leadership communication style, personality trait and organizational productivity through affective event theory.

\subsection{Research Hypotheses}

Arising from the background of the study and the subsequent review of literature, the following hypotheses were generated for testing:

H1: There will be a significant relationship between leadership communication style and personality trait.

H2: There will significant relationship between leadership communication style and organizational productivity.

H3: There will be significant combine effect of leadership communication styles and personality traits on organizational effectiveness.

\section{METHODOLOGY}

Research Design: The study utilized exploratory research design which allows researcher to consider different aspects of a problem understudy. The method was chosen because of its flexibility in discovering new ideas and insights on the relationship

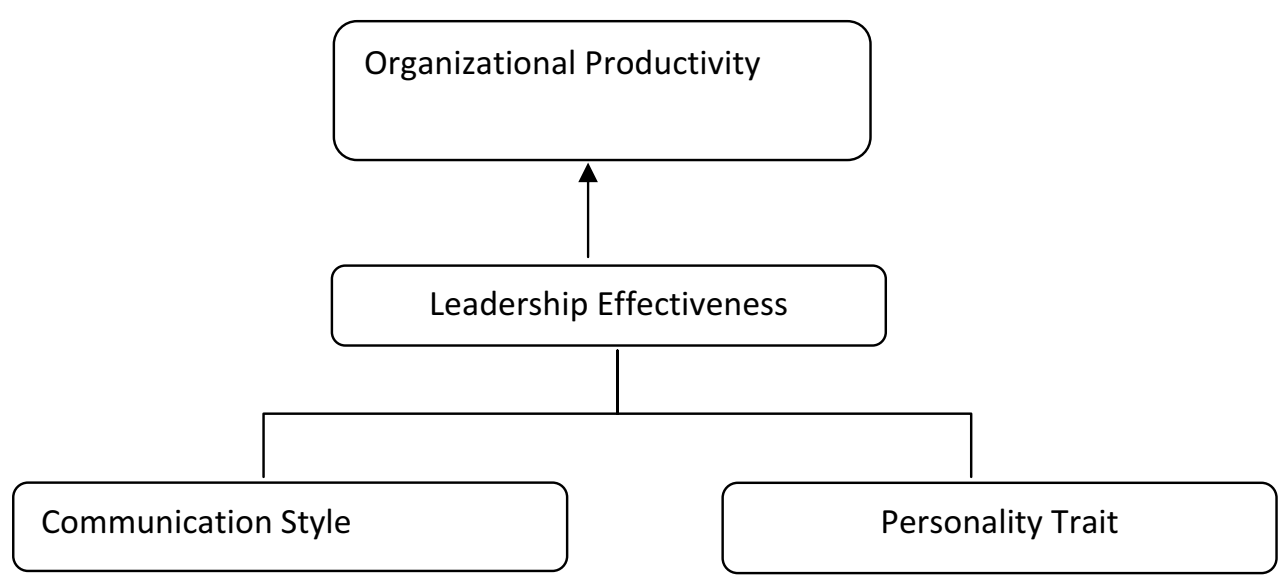

Figure 2. Conceptual framework of relationship between leadership communication style, personality trait and organizational productivity through affective event theory (AET) 
Table 1. Sample distribution

\begin{tabular}{|c|c|c|c|c|}
\hline Faculty & $\begin{array}{l}\text { No. of } \\
\text { Departments in } \\
\text { selected Faculties }\end{array}$ & $\begin{array}{l}\text { No. of } \\
\text { Departments } \\
\text { selected }\end{array}$ & $\begin{array}{l}\text { Names of the selected } \\
\text { Departments }\end{array}$ & $\begin{array}{l}\text { No. of } \\
\text { respondents } \\
\text { selected }\end{array}$ \\
\hline Arts & 9 & 2 & $\begin{array}{l}\text { History and Strategic } \\
\text { Studies } \\
\text { Philosophy }\end{array}$ & 28 \\
\hline Business Administration & 13 & 2 & $\begin{array}{l}\text { Industrial Relation and } \\
\text { Personnel Management } \\
\text { Organizational Behaviour }\end{array}$ & 27 \\
\hline Education & 35 & 2 & $\begin{array}{l}\text { Guidance and Counselling } \\
\text { Manpower Training and } \\
\text { Development }\end{array}$ & 15 \\
\hline Law & 7 & 1 & Public Law & 12 \\
\hline Social Sciences & 12 & 2 & $\begin{array}{l}\text { Sociology } \\
\text { Political Science }\end{array}$ & 30 \\
\hline Total & 76 & 9 & & 112 \\
\hline
\end{tabular}

between the variables understudy.

Subject: Subjects for the study were one hundred and twelve academic staffs of University of Lagos, Nigeria. The calculation for the sample size was conducted through the use of online sample size calculator designed by Raosoft incorporation (2012) at 5\% confidence interval. The total number of academic staff in the selected nine departments was one hundred and fifty-seven (157) out of which sample of one hundred and twelve (112) were drawn for the study.

These subjects were selected through multi-stage sampling technique which includes purposive, stratified, simple random and quota sampling methods. Out of the ten (10) faculties in the institution, five (5) were selected through purposive sampling method. The consideration lies on the fact that University of Lagos, Nigeria is a multicampus institution which spread across a number of geographical locations within
Lagos State. Meanwhile, the study aimed at using the main campus at Akoka, Lagos State, Nigeria where the five selected faculties are located. Afterward, stratified and simple random sampling methods were used to pick nine (9) out of the seventy-six (76) departments in the selected faculties. Thereafter, quota sampling technique was employed to select respondents from the nine (9) departments with special emphasis on size of staffs, choice of element within the strata and characteristic of respondents to be sampled. This was done in order to include all the characteristics that make up the population for ensuring adequate representation and ability to gather needed information from the subject. The information on sample distribution is presented in table 1.

Research Instrument: The instrument used in this study is a close ended questionnaire that was designed by the researcher. The questionnaire comprised of 
four (4) sections; with section "A" with personality (Buller \& Street, 1991). The comprising eight (8) items seeking scale is a five-point Likert response scale demographic data such as age, sex, status, ranging from 1 (strongly disagree) to 5 level of education etc. Section "B" consists of ten (20) items, which sought to collect information about the relationship between communication style and personality trait in work organization. Section "C" contains ten (10) items on the connection between leader personality trait and productivity. While section "D" consists of ten (10) items to elucidates the effect of communication style and personality traits on organizational productivity. Above all, it is a questionnaire that was designed in resemblance of 5 point Likert scale ranging from Strongly Agree to Strongly Disagree.

i. Communication style scale

Communication style was measure by 20 item questionnaire adapted from communication styles inventory (CSI); a sixdimensional behaviour model and its relation (strongly agree).

\section{ii. Personality trait scale}

Personality trait scale was measure by 10 item questionnaire adopted from ten-item personality inventory (TIPI) which comprise of four major scales (i.e. independent, conscientiousness, extraversion and stability). The measure helps to measure personality traits in individual working in an organization (Yarkoni, 2010). The scale is a five-point Likert response scale ranging from 1 (strongly disagree) to 5 (strongly agree).

\section{iii. Productivity Scale}

Job productivity scale was measured by 10 item adapted from Lam Employment Absence and Productivity Scale (LEAPS). The measure is a self-rated scale that helps provide information on how workers function at work (Lam et al., 2009). This

Table 2. Socio-demographics and employment distribution of respondents

\begin{tabular}{llc}
\hline Variables & Frequency & Percentage \\
\hline Sex & 67 & 59.8 \\
Male & 45 & 40.2 \\
Female & & \\
Marital Status & 31 & 27.7 \\
Single & 78 & 69.6 \\
Married & 3 & 2.7 \\
Widowed & & \\
Age & 25 & 22.3 \\
18-27years & 32 & 28.6 \\
28-37years & 18 & 16.1 \\
38-47years & 37 & 33.0 \\
48 years or above & & \\
Educational Qualification & 49 & 43.8 \\
M.Sc./M.Ed./ M.BA/ professionals qualifications & 40.2 \\
M.Phil./PHD & 45 & 16.0 \\
Professor & 8 & \\
Length of Service & & 11.6 \\
Less than 5yrs & 13 & 34.8 \\
5-10yrs & 39 & 42.9 \\
11-15yrs & 48 & 10.7 \\
16yrs and Above & 12 & 33.0 \\
Cadre/Position & & 36.6 \\
Junior Staff & 37 & 30.4 \\
Intermediate Staff & 41 & \\
Senior Staff & 34 & \\
\hline
\end{tabular}

Source: Field survey, 2014 
scale can also be used to make management decision whether or not an employee should remain in work. Scoring was based on a fivepoint Likert response scale ranging from 1 (strongly disagree) to 5 (strongly agree).

\section{Reliability and Validity of Research} Instrument: In order to establish the reliability of this instrument, a pilot study was carried out on a sample of twenty (20) academic staff of the same institution, using a test-retest method. The research used a testretest approach to ascertain the level of validity and reliability of the research instrument that was used in collecting data for this work; Cronbach alpha of 0.87 was obtained showing that the instrument is reliable. In confirming the validities of the instrument, face and content validities were ensured by conference of experts. Hence, Pearson Product Moment Correlation coefficient and Analysis of Variance were used to test the earlier formulated research hypotheses at 0.05 level of significance.

Procedure: The subjects were given the questionnaire in their place of work. Instruction on how to fill the questionnaire was given. Confidential treatment of information was assured. With regard to the scoring of responses, the first section of the questionnaire needs no score attached to it, since the information required are demographic data of the subject. The second, third and fourth sections that is " $\mathrm{B}$ " " $\mathrm{C}$ " and "D" include close-ended questions with rating scores.

Ethical Considerations: Authorization was sought from the management of the organization before conducting the field work. Likewise, consent of the respondents were sought and obtained before the questionnaires were distributed. All the respondents were made to know that they are free to back out of the study at any point in time and that information obtained from them as well as their identities will be kept anonymous and strictly confidential.

\section{RESULTS}

Participants: The respondents for this study comprised of 112 academic staff of University of Lagos, Nigeria. A total of 67 (59.8\%) respondents were males, 45 (40.2\%) were females, $31(27.7 \%)$ were single, 78 $(69.6 \%)$ were married while 3 (2.7) were widowed. Also, $25(22.3 \%)$ of the respondents were between the age bracket 18-27years, $32(28.6 \%)$ were between $28-37$

Table 3. Correlation between leadership communication style and personality trait

\begin{tabular}{|c|c|c|c|c|c|c|c|c|}
\hline \multirow{2}{*}{$\begin{array}{l}\text { Leadership } \\
\text { Communication } \\
\text { Styles }\end{array}$} & \multicolumn{8}{|c|}{ Personality Trait } \\
\hline & $\begin{array}{l}\text { Locus } \\
\text { control }\end{array}$ & of & Authoritarianism & Machiavellianism & Self-esteem & Self-monitoring & Risk Taking & Sig \\
\hline Dramatic & .219 & & .118 & .209 & .821 & .512 & .104 & 0.001 \\
\hline Contentious & .627 & & .639 & .798 & .007 & -.124 & .202 & 0.001 \\
\hline Animated & .530 & & .105 & .554 & .102 & .043 & .434 & 0.05 \\
\hline Relaxed & -.192 & & -.175 & .060 & .599 & .082 & .580 & 0.001 \\
\hline Attentive & .253 & & -.651 & .007 & .201 & .039 & .100 & 0.001 \\
\hline Open & .319 & & -.515 & .142 & .373 & .739 & .292 & 0.001 \\
\hline Friendly & .206 & & .075 & .039 & .634 & .302 & .089 & 0.05 \\
\hline Precise & .223 & & .110 & .263 & .717 & .307 & .696 & 0.001 \\
\hline
\end{tabular}


years, $18(16.1 \%)$ were $38-47$ years and 37 $(33.0 \%)$ were between 48years and above. With regard to educational attainment, 49(43.8\%) were M.Sc/M.Ed./M.BA/ Professional qualification holders, 45 (40.2\%) were M.Phil./PhD holders, while 8 $(6.0 \%)$ were professors. Moreover, the length of service revealed that $13(11.6 \%)$ had been working in the institution for less than 5years, 39(34.8\%) had spent between 510 years while $48(42.9 \%)$ had spent between $11-15 y e a r s$ and $12(10.7 \%)$ had spent 16yrs and above. In addition, $37(33.0 \%)$ were junior staffs, $41(36.6 \%)$ were intermediate while $34(30.4 \%)$ were senior staff of the institution. See the information on table 2 .

Hypothesis 1: There will be a significant relationship between leadership communication styles and personality trait.

The hypothesis was put to test using correlation.
The result in table 3 revealed that there is relationship between leadership communication style and personality trait. The result gives support to the hypothesis. Therefore, the first hypothesis was accepted. It further reveals that out of the communication styles that determines personality trait, relaxed $(\mathrm{r}=-.192)$, attentive $(\mathrm{r}=-.175 ; \mathrm{r}=-.651$ respectively), open $(\mathrm{r}=-$ $.515)$ and contentious ( $\mathrm{r}=-.124)$ in some instances had negative co varies with observed constructs used to explain the relationship between the studied variables. This implies that communication style such as relaxed, attentive, open and contentious sometimes may fail in influencing personality traits of subordinates towards attaining increase productivity and performance in work organization.

\section{Hypothesis 2: There will significant relationship between leadership}

Table 4. Relationship between employee's communication style and organizational productivity

\begin{tabular}{lllllll}
\hline & \multicolumn{2}{l}{ Unstandardized coefficients } & $\begin{array}{l}\text { Standardized } \\
\text { coefficients }\end{array}$ & T & Sig & Remarks \\
\cline { 2 - 5 } & $\mathrm{B}$ & \multicolumn{2}{l}{ Std. Error } & & & \\
\hline Dominant & .508 & .216 & .285 & 1.634 & -.230 & NS \\
Dramatic & .455 & .198 & .213 & 1.529 & .010 & $*$ \\
Contentious & .480 & .160 & .223 & 1.110 & -.317 & NS \\
Animated & .307 & .102 & .090 & 1.423 & -.369 & NS \\
Impression leaving & .245 & .018 & .003 & 2.633 & .032 & $*$ \\
Relaxed & .211 & .012 & .160 & 0.592 & .027 & $*$ \\
Attentive & .433 & .251 & .238 & 1.545 & .012 & $*$ \\
Open & .349 & .111 & .072 & 2.382 & .000 & $*$ \\
Friendly & .354 & .126 & .307 & 4.314 & .004 & $*$ \\
Precise & .515 & .219 & .238 & 2.366 & .020 & $*$ \\
\hline
\end{tabular}

*Correlation is Significant at the 0.05 Level (2-tailed)

Table 5. Combined effects of leadership communications style, personality trait and organizational effectiveness

\begin{tabular}{|c|c|c|c|c|c|c|}
\hline REGRESSION & & ANOVA & & & & \\
\hline Model & Source & $\begin{array}{l}\text { Sum of } \\
\text { Squares }\end{array}$ & Df & Mean square & $\mathrm{F}$ & Sig \\
\hline $\mathrm{R}=120^{\mathrm{a}}$ & Regression & 1062.449 & 8 & 531.224 & 10.067 & $.0347^{\mathrm{a}}$ \\
\hline $\mathrm{R}^{2}=0.54$ & Residual & 73154.885 & 104 & 497.652 & & \\
\hline Adj. $R_{2}=.001$ & Total & 74217.333 & 112 & & & \\
\hline
\end{tabular}


communication style and organizational productivity. The hypothesis was put to test using correlation coefficient.

The result in table 4 depict that there is relationship between leadership communication style and organizational productivity. Thus; hypothesis 2 is accepted. However, only seven out of the leadership communication styles; dramatic $(\mathrm{t}=1.529$; $\mathrm{p}$ value .010), impression leaving ( $\mathrm{t}=2.633$; $\mathrm{p}$ value .032$)$, relaxed ( $\mathrm{t}=0.592 ; \mathrm{p}$-value .027$)$, attentive $(\mathrm{t}=1.545$; $\mathrm{p}$-value .012$)$, open $(\mathrm{t}=$ 2.382; p-value .000), friendly $(\mathrm{t}=4.314 ; \mathrm{p}$ value .004) and precise $(\mathrm{t}=2.366$; $\mathrm{p}$-value .020) have significant relationship on organizational productivity. Similarly, the result indicates that open $(p$-value $=.000)$ and friendly $(p$-value $=.004)$ communication styles have high impact on organizational productivity. The implication is that leaders who are open and friendly in communication will understand their co-workers better which will help to reduce workplace stress and improve employee's satisfaction and cooperation. In such situation, leaders get full support and cooperation from his/her subordinates which in turn led to increase productivity and simultaneous increase profitability.

Hypothesis 3: There will be a significant combined effect of leadership communication styles and personality traits on organizational effectiveness. The hypothesis was put to test, using regression analysis.

The result in table 5 indicate that leadership communication style and personality trait have significant effect on organizational effectiveness $(\mathrm{R}=120 \mathrm{a}$; $\mathrm{R} 2=$ $\mathrm{F}(2.149)=10.067 ; \mathrm{p}<0.5)$. The result shows that communication style and personality trait accounted for $54.0 \%$ of the total variance in organizational effectiveness $(\mathrm{R} 2=0.54)$. Hence, the third hypothesis is accepted.

\section{DISCUSSION}

The principal thrust of this study has been to explore the relationship between leadership communication style, personality trait and organizational productivity. The finding of the study revealed that a significant relationship exist between leadership communication style and personality trait. The finding supports Ajila et al. (2012) who observed that personality trait can be used to predicts workplace behaviour in terms of observable and unobservable things that people do including how productive they are; how much effort they put in their work; how likely they are to continue working rather than quit; how they make decisions and act on these decisions; how they respond to various incentives as well as their attitude toward organizational policies and beliefs in these policies. Consequently, leadership communication style can be determined through personality trait. This implies that all the six measures of personality traits (locus of control, authoritarianism, machiavellianism, selfesteem and self-monitoring) are predictors of communication style and they also determine the method of communication adopted or utilized by managers in contemporary work organizations. It was also depicted in the finding that personality traits predict the method of sending, receiving, processing and retrieving information within and without organizational environment. Leaders with right personality traits are most likely to adopt efficient and effective communication styles in dealing with their subordinates to 
achieve the predetermined organizational goals. As such, the manner at which a leader manage his/her subordinates in terms of information dissemination and feedback responses can either increase or decrease the level of employees' performance, attitude and commitment to organizational productivity.

Consequently, the finding of the study showed that there is a significant relationship between leadership communication style and organizational productivity. This finding tallies with Osemeke (2008), Weihrich and Koontz (1993) who observed that communication is an essential ingredient in collective activities and group efforts geared towards accomplishing a common goal. It is through effective communication styles that work activities can be efficiently assigned, performed and supervised. For a fact, effective communication style is needed at various levels of management for stabilizing variety of personalities, values, and attitudes of employees which are vital components for developing strategic management tactics and for sustaining competitive advantage over other business rivals. Good communication styles and personality traits promote high level of organizational commitment, job satisfaction, work setting, knowledge creation, and acceptance of work responsibility as well as positive subordinate behaviour which often result in increase productivity. On the other hand, poor communication styles and personality traits breed poor commitment, low performance, dissatisfaction, reluctance to organizational change, poor attitude to work, distrustful, judgmental, exploitative etc. which will eventually influence all the factors responsible for organizational productivity (environmental, organizational, managerial and employ-related) negatively leading to poor organizational performance.

In addition, the finding established that there is combine effect of leadership communication style and personality trait on organizational productivity. The finding buttressed Ajila (2014), Den Hartog and Koopman (2011) who submitted that lack of good leadership styles or leaders by example have led to increasing numbers of nonchalant employees with non-productive mind-sets such as: "it does not matter whether there is gain or not, my salary will be paid at the end of the month" "one does not have to sweat when doing government work" "small work, big money" and many other counterproductive attitude to work in many public organizations. There is no gain saying the fact that in a situation where leaders or managers get to work late, there would be high rate of lateness, absenteeism and other forms of workplace indiscipline among the subordinates. On the other hand, in a situation where there is good leadership communication style and personality trait there is bound to be increasing numbers of employees who would cherish the organizational value by wearing expected organizational attitude regardless of the conditions of work. This situation will produce employees that would love to collaborate with the management on decision making process, resource allocation policy designing, innovation, creativity and other crucial aspects of strategic management that may result in increased organizational productivity.

\section{CONCLUSION}

This research set out to explore the relationship between leadership communication style, personality trait and 
organizational productivity. The findings of the study established that there is significant relationship between leadership communication style, personality trait and organizational productivity. Thus, in any organization where there is good leadership communication style and personality trait, increased productivity is inevitable. This is because; effective communication produces healthy relationship between superior and subordinate, work team as well working atmosphere that bring about organizational effectiveness and productivity. Working environment is an important variable that affect organizational behaviour which influences organizational productivity.

On the basis of the research conclusion, the following recommendations are suggested for consideration.

- The managers must employ good leadership communication style when disseminating information that will positively affect productivity in the organization.

- Employers must always test for leadership communication style not on the basis of employment but also on personality test.

- Leaders must allow employee to participate in decision making within the organization in order to allow creativity, sense of belongingness and responsibility that will bring about innovation and development in the organization.

- Employees must be motivated with both intrinsic and extrinsic reward in order to fully achieve the predetermined organizational goals. Therefore, managers need to put in place strategies and policies aimed to reward people fairly, equitable and consistently in accordance with the value of the organization.

- Managers must adopt open communication style which will enable the workers to express and communicate their intentions and suggestions regarding how to enhance productivity in the organization.

\subsection{Managerial Implications}

The outcome of this study can be helpful for leaders or managers in two ways. First, it provides information on how leaders or managers can develop and move smoothly between different communication styles for managing subordinate workers effectively toward achieving the predetermined goals. Secondly, the study shows that personality trait can be tuned or used as a yardstick to determine leadership communication style in any organization. This study clearly shows how leaders for excellent organizational performance and productivity can be ascertained without conducting rigorous laboratory experiment or any psychological test.

\subsection{Limitation and Suggestions for further Study}

It is a recognized fact that no study can be exhaustive in scope. This study has limitations. First, the sample size is relatively low which is due to limited financial and time resources. It is therefore suggested that future study in the area of leadership communication style should investigate factors such as organizational structure, workforce composition, working environment (internal and external), organizational culture, corporate policy, vision and mission statements, external competitors that can hinder leadership communication style in work organization. 


\title{
ИСТРАЖИВАЊЕ ОДНОСА ИЗМЕЪУ КОМУНИКАЦИОНОГ СТИЛА РУКОВОЂЕЊА, ОСОБИНА ЛИЧНОСТИ И ОРГАНИЗАЦИОНЕ ПРОДУКТИВНОСТИ
}

\author{
Oludele Mayowa Solaja, Faremi Elijah Idowu, Adesina Ekundayo James
}

\begin{abstract}
Извод
У организационој пракси и истраживањима, плодна комуникација је значајно повезана са квалитетом лидерских особина. Квалитетно руковођење помаже у ублажавању неуспеха организације, у савладавању све већих пословних изазова који могу довести до расипања ресурса, талената и потенцијала потребних за постизање оптималне организационе продуктивност. Међутим, истраживање релевантне литературе показује да су корпоративни лидери често суочени са изазовом суптилног кретања између различитих стилова комуникације, приликом комуницирања са запосленима уз јасније формулисање идеја и знања кад год су пред њима захтеви који спречавају организациону продуктивност. У том контексту, ова студија истражује однос између комуникационог стила руковођења, особина личности и организационе продуктивности. У истраживању је коришћена метода унакрсног анкетирања. Анкетирано је 112 чланова академског особља Универзитета у Лагосу, Нигерија, који су одабрани применом технике више етапног узорковања. Подаци су прикупљени путем структуираног упитника и личним запажањем. Резултати показују да постоји веза између комуникационог стила руковођења и особина личности. Такође, резултати откривају да комуникациони стил руковођења одређује организацину продуктивност. Шта више, резултати показују да особине личности и комуникациони стилови имају синергетски ефекат на организациону продуктивност. Коначно, обављена је дискусија резултата са освртом на емпиријске резултате присутне у релевантној литератури и истакнуте су препоруке за управљање организацијама, како у праксу, тако и у будућим истраживањима.
\end{abstract}

Кључне речи: руковођење, комуникација, стил, особина личности, продуктивност, организација

\section{References}

Ajila, C.O. (2014). People and Organizations: The Dynamics of Workplace Behaviour. Inaugural Lecture Series 261. Obafemi Awolowo University, Ile-Ife.

Ajila, C.O., Akanni, A.A., \& Ekundayo, O.O. (2012). Leadership and Strategic Human Resource Management in the Nigerian Local Government Councils. U.S.A: Research in Humanities and Social Sciences, 2 (9), 112-121.
Alter, S. (2006). The Work System Method: Connecting People, Processes and IT for Business Results. Working System Press. Larkspur, C.A.

Buller, D.B., \& Street, R.L. Jr. (1991). The role of perceived affected and information in patients' evaluations of health care compliance decisions. Southern Communication Journal, 56, 230-237.

Den Hartog, D., \& Koopman, P. (2011). Leadership in Organizations. Handbook of Industrial, Work and Organizational 
Psychology. Vol. 2. SAGE publications.

DfES (2002). Government Response to the Report of the Council for Excellence in Management and Leadership. Nottingham, DfES Publications.

Digman, J.M., \& Inouye, J. (1986). Further specification of the five robust factors of personality. Journal of Personality and Social Psychology, 50 (1), 116-123.

Dixon, J., Nanni, A., \& Vollman, T. (1990). The new performance challenge: Measuring operations for world class competition. Homewood, il: Irwin.

Feist, J., \& Feist, G.J. (2009). Theories of Personality (7th ed.). New York: Mc GrawHill.

French, W.L., Kast, F.E., \& Rosenzweig, J.F. (1985). Understanding Human Behaviour in Organizations. New York: Harper and Row Publishers.

Funder, D.C. (1997). The Personality Puzzle. New York: W.W. Norton.

Grint, K. (2004). What is Leadership? From Hydra to Hybrid. Working Paper, Said Business School and Templeton College, Oford University.

John, O.P., Naumann, L.P., \& Soto, C.J. (2008). Paradigm Shift to the Integrative Big-Five Trait Taxonomy: History, Measurement, and Conceptual Issues. In O.P. John, R.W. Robins, \& L.A. Pervin (Eds.), Handbook of personality: Theory and research (pp. 114-158). New York, NY: Guilford Press.

Kirtley, M.D, \& Weaver, J.B. III (1999). Exploring the impact of gender role selfperception on communication style. Women's Studies in Communication, 22 (2), 190-209.

Lam, R.W., Michalak, E.E., \& Yatham, L.N. (2009). A new clinical rating scale for work absence and productivity: validation in patients with major depressive disorder.
BMC Psychiatry.

Martinez, D. (2012). Organizational Communication: Small Organizations Must Transition Into a Communication Style That Supports a Culture of Employee and Organizational Growth. A Thesis Presented to the Faculty in Communication and Leadership Studies School of Professional Studies Gonzaga University.

Matthews, G., Deary, I.J., \& Whiteman, M.C. (2003). Personality traits (2nd ed.). Cambridge: Cambridge University Press.

Norton, R.W. (1983). Communicator style: theory, applications and measures. Beverly Hills, CA: Sage.

Nwagwu, J.E. (2014) Effective Leadership: Comparative Analysis of Leadership and Management. International Journal of Management Sciences, (4) 3, 144157.

Osemeke, M. (2008). Effective Communication and Performance Improvement In Nigeria. Journal of Research in National Development, 6 (2).

Phusavat, K. (2007). Roles of performance measurement in SMEs' management processes. International Journal of Management and Enterprise Development, 4 (4), 441-458.

Robbins, S.P., Judge, T.A., \& Sanghi, S. (2009). Organizational Behaviour. U.S.A. Pearson Education, Inc.

Secretary's Commission on Achieving Necessary Skills (1991). What Work Requires of Schools: A SCANS Report for America 2000. Washington, DC: U.S. Department of Labor, (ED 332 054).

Steijn, B. (2001). Work Systems, Quality of Working Life and Attitudes of Workers An Empirical Study towards the effects of Team and non-Teamwork. New Technology, Work, and Employment, 16 (3), 191-203.

The Public Forum Institute (2001). Role 
of Communication in Organization.

Available at www.publicforuminstitute.org retrieved on 19th November, 2014.

Ticehurst, G.W., \& Veal, A.J. (2000). Business research methods: A managerial approach. French Forest, Australia: Addison Wesley Longman.

Weihrich, H., \& Koontz, H. (1993). Management: A global perspective. New York: McGraw Hill.

Weiss, H.M., \& Cropanzano, R. (1996). Affective events theory: A theoretical discussion of the structure, causes, and consequences of affective experiences at work. In B.M. Staw \& L.L. Cummings (eds.), Research in organizational behaviour (vol. 18, pp. 1-74). Greenwich, CT: JAI Press.

Yarkoni, T. (2010). The abbreviation of personality, or how to measure 200 personality scales with 200 items. Journal of Research in Personality, 44, 180-198. 